\title{
Antibacterial Activity Test of Ethanol Extract Pineapple (Ananas comosus (L.) Merr.) Peel against Growth of Propionibacterium acnes
}

Fitriyanti* 10
Muhammad Nur Rahman
Hendrawan
Karunita Ika Astuti
Department of Pharmacy, Sekolah
Tinggi Ilmu Kesehatan Borneo Lestari,
Banjarbaru, South Kalimantan,
Indonesia $\quad$ Seywords:
*email: fitriyantihudari@gmail.com
Antibacterial
Pineapple peel extract
Propionibacterium acnes

\begin{abstract}
Pineapple peel (Ananas comosus (L.) Merr.) is waste from the pineapple fruit. The purpose of this study was to determine the content of pineapple peel extract and to antibacterial activity in various concentrations effective in inhibiting the growth of Propionibacterium acnes. The pineapple peel extract is made by using the extraction method in the form of maceration. The method used in the inhibitory test using the three replication samples in each treatment group. The sample consisted of 10 treatment groups ie pineapple peel extract concentration $12.5 \%, 25 \%, 37.5 \%, 50 \%, 62.5 \%, 75 \%, 87.5 \%$, and $100 \%$, as well as positive and negative control. The results obtained from pineapple peel screening contain flavonoid and saponin compounds. The data analysis shows that pineapple peel extract concentrations of $50 \%, 62.5 \%, 75 \%, 87.5 \%$, and $100 \%$ had inhibitory zones with the medium-strong category while clindamycin as the control has a strong inhibition zone. The conclusion of this research proves that pineapple peel extract has antibacterial power to $P$. acnes with effective concentration is $100 \%$ with the strong category.
\end{abstract}

Received: August 26th 2019

Accepted: October $22^{\text {nd }} 2019$

Published: November 14th 2019

(C) 2019 Fitriyanti, Muhammad Nur Rahman Hendrawan, Karunita Ika Astuti. Published by Institute for Research and Community Services Universitas Muhammadiyah Palangkaraya. This is an Open Access article under the CC-BY-SA License https:// doi.org/10.33084/ bjop.v2i2.928. (http:/ / creativecommons.org/licenses/by-sa/4.0/).

\section{INTRODUCTION}

Acne is a skin disease that attacks more than $85 \%$ of adolescents throughout the world (Lynn et al., 2016). Acne is characterized by the growth of blackheads, inflammation, and nodular cystic acne. Acne can grow based on several factors, namely, excess sebum production, abnormal growth of keratin in the follicles, and the growth of Propionibacterium acnes (Fox et al., 2016; Bergler-Czop \& Brzezińska-Wcisło, 2013).

Propionibacterium acnes belongs to the Corynebacterial group of bacteria. Propionibacterium acnes is the first organism that generally contributes to the occurrence of acne. Propionibacterium acnes belongs to a group of Grampositive, rod-shaped, and non-sporous (McLaughin et al., 2019). Propionibacterium acnes plays a role in the formation of acne by producing lipases that break down free fatty acids from skin lipids. These fatty acids can cause tissue inflammation when related to the immune system and support the occurrence of acne. Treatment of infected acne can be done by reducing the bacterial population by using an antibiotic such as tetracycline, erythromycin, and clindamycin (Lely et al., 2016; Daud et al., 2018).

The use of antibiotics in a long time, the higher the resistant microorganisms (Ventola, 2015). An alternative method that can be taken is by utilizing natural antibacterial, which has the potential to inhibit or kill bacteria, including the causes of acne like P. acnes (Sinha et al., 2014). One of them is pineapple (Ananas comosus (L.) Merr.), which is one of the fruits that are consumed by many people, but only the flesh of the fruit is utilized, while the tubers and the peel only become waste, which 
will eventually become an environmental polluter (Deng et al., 2012).

Previous research revealed that pineapple fruit peel could inhibit the bacteria Streptococcus mutant with concentrations of $25 \%, 50 \%, 75 \%$, and $100 \%$ (Bahtiyar et al., 2017). Also, pineapple fruit peel extract shows antibacterial activity against Enterococcus faecalis (Putri et al., 2016). The purpose of this study was to determine the content of pineapple peel extract and to antibacterial activity in various concentrations effective in inhibiting the growth of $P$. acnes.

\section{MATERIALS AND METHODS}

\section{Materials}

Pineapple peel that has been extracted by maceration, 96\% ethanol, NA media (Nutrient Agar), MHA (Mueller Hinton Agar) media, aquadest, P. acnes bacterial culture provided by the Laboratory of Pharmaceutical Microbiology, University of North Sumatra, Medan, clindamycin antibiotic disk, Na-CMC, concentrated sulfuric acid, Mayer reagent, Dragendorff reagent, Wagner reagent, $\mathrm{HCL}, \mathrm{Mg}$ powder, $\mathrm{FeCl}_{3}$, and chloroform.

\section{Sample preparations}

Pineapple peel samples were obtained from pineapple fruit merchant waste in Banjarbaru, South Kalimantan, which had been previously washed. The pineapple peel is then dried in an oven at $40^{\circ} \mathrm{C}$ and then chopped to a small size and blended to a powder. Pineapple peel powder was then transferred to maceration vessels and extracted using $96 \%$ ethanol solvent in a ratio of $1: 7.5$ (Damogalad et al., 2013), then let stand for three days (stirred every 24 hours) and then filtered using filter paper. Then the extraction was repeated three times for nine days. The macerate is collected and then concentrated with a rotary evaporator with a temperature of $40^{\circ} \mathrm{C}$. After obtaining concentrated extracts with a fixed weight, then the yield obtained from the extraction process is calculated.

\section{Phytochemistry tests}

Alkaloid test

Pineapple peel extract $0.5 \mathrm{ml}$ of $2 \% \mathrm{HCl}$ and the solution was divided into two tubes. The tube I added 2-3 drops of Dragendorff reagent, tube II added 2-3 drops of Mayer reagent. Orange precipitates indicate the presence of alkaloids in the tube I and white deposits in tube II (Ngibad, 2019).

\section{Flavonoid test}

The extract was weighed as much as $0.5 \mathrm{~g}$. As much as 0.1 $\mathrm{g}$ of $\mathrm{Mg}$ powder and $2 \mathrm{ml}$ of $2 \mathrm{~N} \mathrm{HCl}$ were added to $2 \mathrm{ml}$ of extract solution. Flavonoid compounds will show orange to red (Nurhasnawati et al., 2019).

\section{Saponin test}

As much as $0.5 \mathrm{~g}$ of the extract, then added with $2 \mathrm{ml}$ of water until all parts of the extract were submerged and then shaken vigorously. There is foam after shaking, and the foam is waited for ten minutes to remain constant, then the positive extract contains saponin compounds (Mir et al., 2016).

\section{Tannin test}

As much as $0.5 \mathrm{~g}$ of extract added $3 \mathrm{ml}$ of warm water. The extract was tested with $1-2$ drops of $\mathrm{FeCl}_{3} 1 \%$, formed dark blue or blackish green, indicating the presence of tannin compounds.

\section{Steroid test}

As much as $0.5 \mathrm{~g}$ of extract was put into a test tube, dissolved in $0.5 \mathrm{ml}$ chloroform and then added with 0.5 $\mathrm{ml}$ anhydrous acetic acid. This mixture is then added to 1-2 $\mathrm{ml}$ of concentrated sulfuric acid through the tube wall. The presence of a triterpenoid is indicated by the presence of a brownish or violet ring at the border of two solvents, while the presence of steroids is indicated by the presence of a bluish-green color (Mandal et al., 2013). 


\section{Antibacterial test}

Three Petri dishes were prepared, where two plates were used for samples, each divided into four sections, while the remaining one dish was divided into two sections for positive and negative control. As a positive control, clindamycin was used, while negative control was used MHA media. The $20 \mu \mathrm{l} \mathrm{P}$. acnes culture inoculate suspension was then transferred into each petri dish by micropipette using the spread plate method. (Sanders, 2012).

In each petri dish, a well is made and then filled with samples of pineapple peel extract of various concentrations as well as the positive and negative control in laminar air flow. Each petri dish is then transferred to the refrigerator at $4^{\circ} \mathrm{C}$ for 24 hours until the sample diffuses into the media, then incubated at $37^{\circ} \mathrm{C}$ for 24 hours (Debalke et al., 2018). Furthermore, the diameter of the inhibition zone (bright or clear zone) is measured using a ruler. The whole process was repeated three times, and then the inhibition zone calculations were performed for each sample concentration.

\section{RESULTS AND DISCUSSION}

Phytochemical screening is carried out to identify the content of secondary metabolites contained in $96 \%$ ethanol extract of pineapple fruit peel so that it can be known what secondary metabolites are likely to have antibacterial activity. The results of screening can be seen in Table I. Pineapple peel containing saponins and flavonoids. This is according to research from Yeragamreddy et al. (2013) that pineapple peel contains saponins and flavonoids. The mechanism of action of saponins as an antibacterial is to reduce surface tension resulting in cell leakage and cause intracellular fluid to come out (Nuria et al., 2009).

Furthermore, pineapple peel also contains flavonoids. Flavonoid compounds are disinfecting and play a role in inhibiting the growth of Gram-positive bacteria. Flavonoids are polar, so it is easier to penetrate the peptidoglycan layer, which is also polar in Gram-positive bacteria than it is in the non-polar lipid layer. On the walls of Gram-positive bacterial cells contain polysaccharides, which are a water-soluble polymer, which functions as a transfer of positive ions to get in and out. It is this solubility which shows that the Gram-positive cell wall is more polar than Gram-negative cell. After entering, the flavonoids work to destroy bacteria by denaturing proteins that can cause metabolic activity. Bacterial cells stop because all bacterial cell metabolic activities are catalyzed by an enzyme, which is a protein. Cessation of metabolic activity will result in bacterial cell death (Osonga et al., 2019; Echeverria et al., 2017).

\begin{tabular}{llc} 
Table I. & \multicolumn{2}{c}{ Phytochemical screening of pineapple peel extract } \\
\hline Test & \multicolumn{1}{c}{ Reagent } & Result \\
\hline Alkaloid & Dragendorff & - \\
& Mayer & - \\
Flavonoid & Mg and $\mathrm{HCl} \mathrm{2N}$ & + \\
Saponin & Aquadest & + \\
Tannin & $\mathrm{FeCl}_{3}$ & - \\
Steroid & Liebermann-Burchard & - \\
\hline
\end{tabular}

Various inhibition zone diameters were obtained, which were formed from each concentration of pineapple peel extract solution used in the study. The increasing concentration of pineapple peel extract solution shows that there is an increase in the inhibition zone diameter. The result of the inhibition zone can be observed in Table II and Figure 1. Based on the test results of data analysis with SPSS shows there are differences in inhibition zone values in negative control and concentrations of $12.5 \%$, $25 \%$, and $37.5 \%$, while between concentrations of $50 \%$, $62.5 \%, 75 \%, 87,5 \%$ and $100 \%$ and positive controls were significantly different. The average value of the inhibition zone in the negative control and composition $12.5 \%, 25 \%$, and $37.5 \%$ determine the lowest value of $0 \mathrm{~mm}$ while the average value of the inhibition zone in the positive control shows the highest value of $19.33 \mathrm{~mm}$. Table II 
also shows a significant increase in inhibition zones each period after the concentration of pineapple peel extract by $37.5 \%$ to $100 \%$. The categorizing of the results was based on Davis \& Stout (1971), who mentioned that the antibacterial inhibition zone with diameter $>20 \mathrm{~mm}$ means very strong, $10-20 \mathrm{~mm}$ means strong, 5-10 mm means medium, and $<5 \mathrm{~mm}$ indicates weak inhibition. Based on these categories, the pineapple extract with a concentration of $100 \%$ is in a strong category, while at a concentration of 50 to 87.5 is in the medium category.

Table II. Inhibition zone of pineapple peel extract for P. acnes

\begin{tabular}{lcc}
\hline \multicolumn{1}{c}{ Sample } & $\begin{array}{c}\text { Inhibition zone } \\
\text { diameter }(\mathbf{m m})\end{array}$ & $\begin{array}{c}\text { 泣andard } \\
\text { deviation }(\mathbf{m m})\end{array}$ \\
\hline Negative control & 0 & 0 \\
Positive control & 19.33 & 0.57 \\
Extract $12.5 \%$ & 0 & 0 \\
Extract $25 \%$ & 0 & 0 \\
Extract $37.5 \%$ & 0 & 0 \\
Extract $50 \%$ & 5.17 & 0.29 \\
Extract $62.5 \%$ & 6.67 & 0.29 \\
Extract $75 \%$ & 7.33 & 0.29 \\
Extract $87.5 \%$ & 8.17 & 0.29 \\
Extract $100 \%$ & 10.17 & 0.76 \\
\hline
\end{tabular}

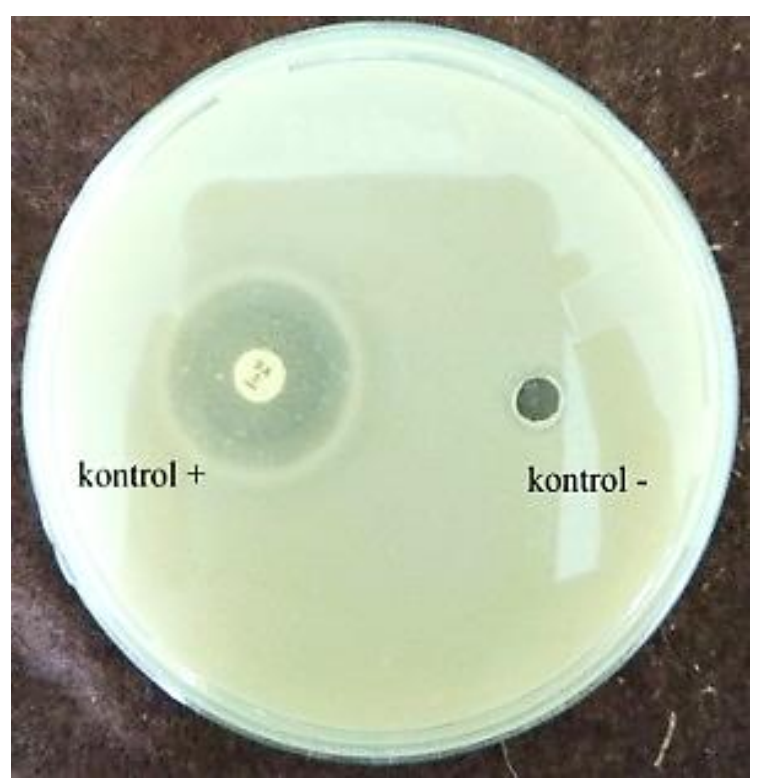

a

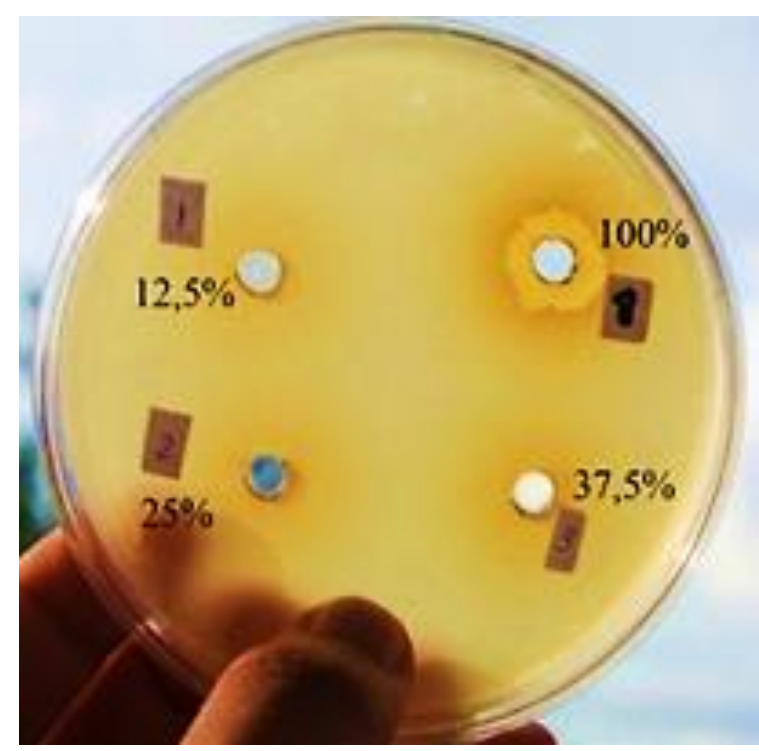

b

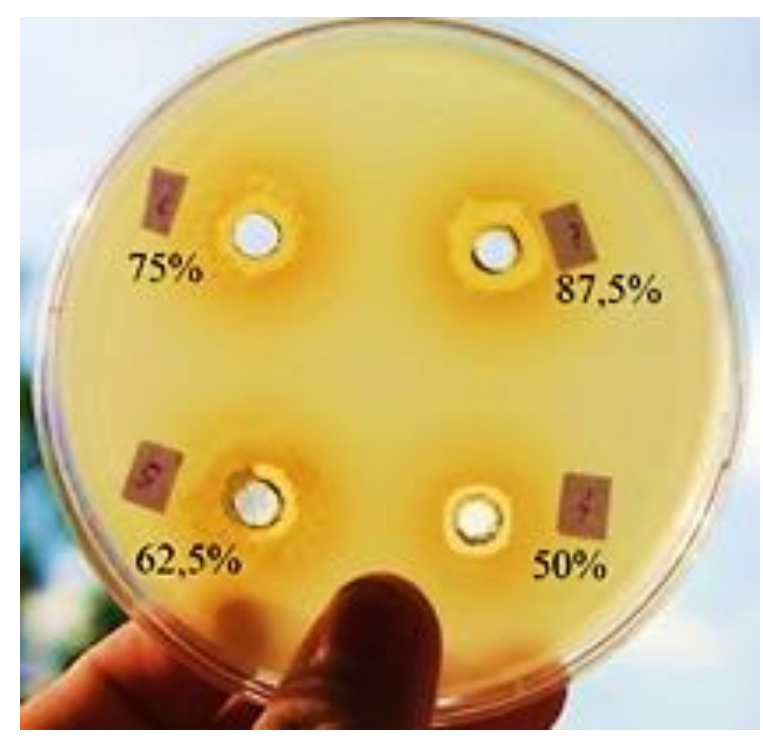

c

Figure 1. The antibacterial test results of positive and negative control (a), 96\% ethanol extract of pineapple peels with a concentration of $12.5 ; 25 ; 37.5$; and $100 \%$ (b) as well as and 50 ; $62.5 ; 75 ;$ and $87.5 \%(\mathbf{c})$ against $P$. acnes

\section{CONCLUSION}

The results of the research can be concluded that: pineapple peel extract contains compounds flavonoids and saponins, which have an antibacterial effect on the growth of $P$. acnes. Ethanol extract of pineapple peel has a strong category at a concentration of $100 \%$ on P. acnes growth with an average inhibition zone diameter of 10.16 $\mathrm{mm}$. 


\section{REFERENCES}

Bahtiyar, A.Y., Efriyadi, O., Fitriah, E. 2017. Efektivitas Kandungan Anti-Bakteri Buah Nanas (Ananas comosus L. Merr) dalam Menghambat Pertumbuhan Bakteri Streptococcus mutans. In Proceeding of Seminar Nasional Sains \& Entrepreneurship IV. August 26 $6^{\text {th }}$ 2017, Semarang: Universitas PGRI Semarang.

Bergler-Czop, B., Brzezińska-Wcisło, L. 2013. Dermatological problems of the puberty. Advances in Dermatology and Allergology. 30(3):178-187.

https://dx.doi.org/10.5114/pdia.2013.35621

Damogalad, V., Edy, H.J., Supriati, H.S. 2013. Formulasi Krim Tabir Surya Ekstrak Kulit Nanas (Ananas comosus L Merr) dan Uji In Vitro Nilai Sun Protecting Factor (SPF). Pharmacon. 2(2):39-44.

Daud, N.S., Akbar, A.J., Nurhikma, E., Karmilah, K. 2018. Formulation of Snail Slime (Achatina Fulica) Anti-Acne Emulgel using Tween 80-Span 80 as Emulsifying and HPMC as Gelling Agent. Borneo Journal of Pharmacy. 1(2):64-67. https://doi.org/10.33084/bjop.v1i2.369

Debalke, D. Birhan, M., Kinubeh, A., Yayeh, M. 2018. Assessments of Antibacterial Effects of Aqueous-Ethanolic Extracts of Sida rhombifolia's Aerial Part. The Scientific World Journal. 2018:8429809. https://dx.doi.org/10.1155/2018/8429809

Deng, G.F., Shen, C., Xu, X.R., Kuang, R.D., Guo, Y.J., Zeng, L.S., Gao, L.L., Lin, X., Xie, J.F., Xia, E.Q., Li, S., Wu, S., Chen, F., Ling, W.H., Li, H.B. 2012. Potential of Fruit Wastes as Natural Resources of Bioactive Compounds. International Journal of Molecular Sciences. 13(7):8308-8323.

https://dx.doi.org/10.3390/ïms13078308

Echeverria, J., Opazo, J., Mendoza, L., Urzua, A., Wilkens, M. 2017. Structure-Activity and Lipophilicity Relationships of Selected Antibacterial Natural Flavones and Flavanones of Chilean Flora. Molecules. 22(4):608. https://dx.doi.org/10.3390/molecules220406 08

Fox, L., Csongradi, C., Aucamp, M., du Plessis, J., Gerber, M. 2016. Treatment Modalities for Acne.
Molecules.

21(8):1063.

https://dx.doi.org/10.3390/molecules210810 63

Lely, N., Firdiawan, A., Martha, S. 2016. Efektivitas Antibakteri Minyak Atsiri Rimpang Jahe Merah (Zingiber officinale var. Rubrum) Terhadap Bakteri Jerawat. Scientia: Jurnal Farmasi dan Kesehatan. 6(1):44-49. http://dx.doi.org/10.36434/scientia.v6i1.41

Lynn, D.D., Umari, T., Dunnick, C.A., Dellavalle, R.P. 2016. The epidemiology of acne vulgaris in late adolescence. Adolescent Health, Medicine and Therapeutics.

7:13-25. https://dx.doi.org/10.2147/AHMT.S55832

Mandal, S., Patra, A., Samanta, A., Roy, S., Mandal, A., Mahapatra, T.D., Pradhan, S., Das, K., Nandi, D.K. 2013. Analysis of phytochemical profile of Terminalia arjuna bark extract with antioxidative and antimicrobial properties. Asian Pacific Journal of Tropical Biomedicine. 3(12):960-966.

https://dx.doi.org/10.1016/S22211691(13)60186-0

McLaughin, J., Watterson, S., Layton, A.M., Bjourson, A.J., Barnard, E., McDowell, A. 2019. Propionibacterium acnes and Acne Vulgaris: New Insights from the Integration of Population Genetic, Multi-Omic, Biochemical and Host-Microbe Studies. Microorganisms. 7(5):128.

https://dx.doi.org/10.3390/microorganisms 7050128

Mir, M.A., Parihar, K., Tabasum, U., Kumari, E. 2016. Estimation of alkaloid, saponin and flavonoid, content in various extracts of Crocus sativa. Journal of Medicinal Plants Studies. 4(5):171-174.

Ngibad, K. 2019. Phytochemical Screening of Sunflower Leaf (Helianthus annuus) and Anting-Anting (Acalypha indica Linn) Plant Ethanol Extract. Borneo Journal of Pharmacy. 2(1):24-30. https://doi.org/10.33084/bjop.v2i1.689

Nurhasnawati, H., Sundu, R., Sapri, Supriningrum, R., Kuspradini, H., Arung, E.T. 2019. Antioxidant activity, total phenolic and flavonoid content of several indigenous species of ferns in East Kalimantan, Indonesia. Biodiversitas. 20(2):576580.

https://doi.org/10.13057/biodiv/d200238 
Nuria, M.C., Faizatun, A., Sumantri. 2009. Uji Aktivitas Antibakteri Ekstrak Etanol Daun Jarak Pagar (Jatropha curcas L) terhadap Bakteri Staphylococcus aureus ATCC 25923, Escherichia coli ATCC 25922, dan Salmonella typhi ATCC 1408. Mediagro: Jurnal Ilmu-Ilmu Pertanian. 5(2):26-37.

Osonga, F.J., Akgul, A., Miller, R.M., Eshun, G.B., Yazgan, I., Akgul, A., Sadik, O.A. 2019. Antimicrobial Activity of a New Class of Phosphorylated and Modified Flavonoids. ACS Omega. 4(7):1286512871.

https://dx.doi.org/10.1021/acsomega.9b000

77

Putri, R.M.A., Yuanita, T., Roelianto, M. 2016. Daya Anti Bakteri Ekstrak Kulit Nanas (Ananas comosus) terhadap Pertumbuhan Bakteri Enterococcus Faecalis. Conservative Dentistry Journal. 6(2):1-6.

Sanders, E.R. 2012. Aseptic Laboratory Techniques: Plating Methods. Journal of Visualized Experiments. 63:3064.

https://dx.doi.org/10.3791/3064

Sinha, P., Srivastava, S., Mishra, N., Yadav, N.P. 2014. New Perspectives on Antiacne Plant Drugs: Contribution to Modern Therapeutics. BioMed Research International. 2014:301304. https://dx.doi.org/10.1155/2014/301304

Ventola, C.L. 2015. The Antibiotic Resistance Crisis. Part 1: Causes and Threats. Pharmacy and Therapeutics. 40(4):277-283.

Yeragamreddy, P.R., Peraman, R., Routhu, H., Babu, N. 2013. In Vitro Antitubercular and Antibacterial Activities of Isolated Constituents and Column Fractions from Leaves of Cassia occidentalis, Camellia sinensis and Ananas comosus. African Journal of Pharmacology and Therapeutics. 2(4):116-123. 